\title{
An Immunohistological Evaluation of Pseudomonas aeruginosa Pulmonary Infection in Two Patients with Cystic Fibrosis
}

\author{
DAVID P. SPEERT, JAMES E. IDIMMICK. GERAID B. PIER. JAMES M. SAUNDERS, \\ ROBERT E. W. HANCOCK. AND NIAMH KEILY

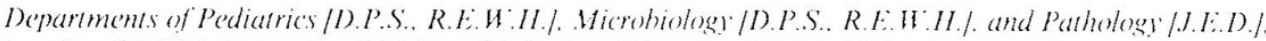

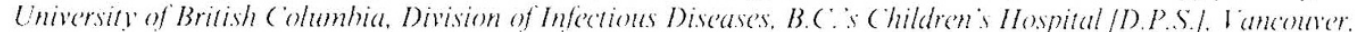

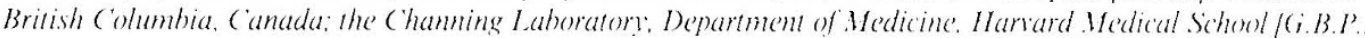 \\ J.M.S./. and Brigham and Women's Hospital /G.B.P.. J.H.S./. Bostom. Wassachusetts
}

\begin{abstract}
ABSIRACI. Pseudomonas aeruginosa is the principal pulmonary pathogen in patients with cystic fibrosis. All attempts to date to prevent or eradicate $P$. aeruginosa infections in these patients have been unsuccessful. Vaccination against $P$. aeruginosa has been proposed as a preventive strategy but it has not been adequately evaluated. The purpose of this study was to determine whether $P$. aeruginosa, present in the lungs of patients with cystic fibrosis, express surface antigens similar to those grown in vitro; this issue is of critical importance when choosing bacterial products as vaccine candidates. I ung sections from two patients who died of the pulmonary complications of cystic fibrosis were studied. Bacteria, both in lung sections and isolated from the lung sections and grown in vitro, reacted strongly with polyclonal and monoclonal antibodies against $P$. aeruginosa mucoid exopolysaccharide and outer membrane proteins $\mathrm{F}$ and $\mathrm{H} 2$; this suggested that these antigens are surface exposed in vivo. It was also found that bacteria in both lung sections were associated in situ with $\operatorname{IgG}, \operatorname{IgA}$, and $\mathrm{C} 3$ but not with $\operatorname{IgM}$ or $\mathrm{C} 4$. (Pediatr Res 22: 743-747, 1987)
\end{abstract}

\section{Abbreviations}

CF, cystic fibrosis

MEP, mucoid exopolysaccharide

SDS-PAGE, sodium dodecyl sulfate polyacrylamide gel electrophoresis

I.PS, lipopolysaccharide

PBS/FCS, phosphate-buffered saline with $1 \%$ fetal calf serum

Psetudomonas aeruginosa is associated with pulmonary infections in most patients with $C F$ ( 1 ). Although $P$. acruginosa is thought to be the principal CF bacterial pathogen. many questions regarding its role in the disease process remain unanswered. The unique host-parasite relationship in the CF lung is characterized by chronic infection that ultimately leads to fatal pul-

Received Fibruary 23, 1987: accepted August 14, 1987

Correspondence and reprint requests Dr. David P Speert. Research (entre. \#304-950 Wes 28 h Avenue Vancouver. B. C'anada V5Z 4114

Supported by a grant to D.P.S. from the (anadian (ystic Fibrosis Foundation. to R.I:W.II by a Medical Research (ouncil of ('anada grant, and to (i.B.P. by a grant from the National Institutes of Allergy and Infectious Diseases. D.P.S. is a scholar of the (anadian ('ystic Fibrosis Foundation and G.B.P. is a Research Scholar of the US. Cystic Fibrosis Foundation. monary insufficiency. The progressive infection evolves despite the presence of high levels of anti-Pseudomonal immunoglobulins in serum and sputum. Furthermore. CF host defenses appear to be largely intact (2). and (F phagocytic cell function in essentially normal (2). However, serum and sputum anti-Pseudomonal $\lg \mathrm{G}$ may be deficient in the $\mathrm{Fe}$ portion (3). Consequently. it has been suggested that these molecules lack the capacity to opsonize Pseudomonas for ingestion by alveolar macrophages (3).

Observations regarding the pathophysiology of $P$. acrusinose infections in $\mathrm{CF}^{2}$ have been derived largely from in vitro investigations. The bacteria have been grown on artificial media and might differ significantly from those present in sill in the ( $\mathrm{F}$ lung. Brown et al. (4) have demonstrated with $P$. aeruginusis isolated from CF sputum without further subculture that the outer membranes contain, in addition to their normal complement of major proteins, a series of high molecular weight proteins. These proteins are present in vitro only after the bacteria are grown on iron-restricted media. However, while these investigations have demonstrated reasonable conservation of outer membrane proteins (with the exception noted above). they do not show that outer membrane protein antigens are exposed in vive and available as targets for immunotherapy.

We were recently presented with the opportunity to evaluate antigens expressed by bacteria present in situ in the lungs of two patients with CF. Both patients died as the result of chronic progressive pulmonary disease and had postmortem examinations. We compared their bacteria grown in vitro and present in situ in lung sections in :erms of reaction with antibodies directed against specific $P$. aer iginosa surface components. We also investigated the nature of the immunoglobulin present on the bacteria in these lung sections. The observations from these studies form the basis of this report.

\section{MATERIALS AND MITHOOSS}

(ase histories. Patient I. An East Indian girl was diagnosed as having $C F$ in the neonatal period by the serum immunoreactive trypsin test. This was confirmed by a sweat chloride of 104 and a sweat sodium of $74 \mathrm{mEq} /$ liter. Her initial problems were associated with gastroesophageal reflux that failed to respond to medical or surgical therapy. She developed persistent and progressive pulmonary infiltrative disease that was probably exacerbated by aspiration of gastric contents. Culture of her throat first grew Pseudomonas maltophilia at 13 months of age. $P$. acruginosa was first recovered from a throat culture at 36 months of age. Both organisms persisted in her respiratory secretions until the time of death. She received multiple courses of antibi- 
otics including ticarcillin, tobramycin, chloramphenicol, and moxalactam but the $P$. maltophilia became resistant to all drugs. Since $P$. aeruginosa infection in the patient's lungs was documented for only 3 months prior to death, we consider the patient's colonization by $P$. aeruginosa to be atypical of the usual CF lung infections. In agreement with this, mucoid $P$. aeruginosa strains that often appear only after some years of chronic infection, were not recoverable from the lungs of this patient. She died from pulmonary insufficiency at 39 months of age. Her tracheobronchial tree was extensively plugged with mucopurulent material that grew $P$. maltophilia and two nonmucoid strains of $P$. aeruginosa differentiated on the basis of colonial morphology.

Patient 2. A Caucasian girl was diagnosed as having $\mathrm{CF}$ at 16 months of age when she presented with a history of recurrent respiratory infections and malabsorption. Her sweat chloride was 119 and sweat sodium was $99 \mathrm{mEq} /$ liter. She was treated with pancreatic enzyme replacement, physiotherapy, and intermittent anti-Staphylococcal antibiotics. P. aeruginosa was first recovered from her sputum at $7 \mathrm{yr}$ of age but was not persistently present until she was $10 \mathrm{yr}$ old. Mucoid $P$. aeruginosa was recovered from sputum when she was $11 \mathrm{yr}$ of age and persisted until the time of her death. She was first admitted to the hospital for treatment of a pulmonary infection at $10 \mathrm{yr}$ of age and readmitted 12 times over the next $5 \mathrm{yr}$ for therapy with intravenous antibiotics. Her $P$. aeruginosa isolate developed resistance to ticarcillin and tobramycin. On her last hospitalization, she was treated with ciprofloxacin to which her isolate was susceptible. She died from pulmonary insufficiency at $15 \mathrm{yr}$ of age. At postmortem examination, her tracheobronchial tree was plugged with tenacious mucopurulent material that grew mucoid and nonmucoid colonial types of $P$. aeruginosa.

Bacterial strains. Mucopurulent secretions from the distal mainstem bronchus were obtained from patients 1 and 2 at postmortem examination and cultured in the Diagnostic Microbiology Laboratory of B.C.'s Children's Hospital. P. aeruginosa was identified by standard means. Mucoid and nonmucoid variants were distinguished by conventional macroscopic criteria (5). The culture from patient 1 yielded two different nonmucoid $P$. aeruginosa colonial variants $(\mathrm{C} 1271 \mathrm{C}$ and $\mathrm{C} 1272 \mathrm{C})$ and one strain of $P$. maltophilia $(\mathrm{C} 1273 \mathrm{C})$. The culture from patient 2 yielded a mucoid $(\mathrm{C} 1295 \mathrm{M})$ and a nonmucoid (C1280NM) strain of $P$. aeruginosa. For outer membrane experiments, colonies from primary cultures, obtained as above, were recultured on proteose peptone no. 2 agar, and overnight cultures in proteose peptone no. 2 broth were inoculated from a single colony.

Antibodies to outer membrane proteins. Rabbit antiouter membrane antibodies were produced exactly as described (6). Monoclonal antibodies MA5-8 (antiprotein F) and MA 1-6 (antiprotein H2) were prepared against $P$. aeruginosa outer membrane proteins as described $(7,8)$. These antibodies were isolated by growth of their respective producing hybridomas in ascites in mice (7) and partially purified by ammonium sulfate precipitation.

Antibodies to mucoid exopolysaccharide. Polyclonal rabbit antibodies raised to purified MEP from $P$. aeruginosa strain 2192 were prepared as described previously (9). Affinity purified rabbit antibodies to MEP were prepared from the above sera as described previously (10). Monoclonal mouse antibodies to MEP were derived from BALB/c mice immunized intraperitoneally with killed bacterial cells or MEP (10 $\mu \mathrm{g} /$ injection) on alternating days for $2 \mathrm{wk}$. Three days prior to the cell fusion, the mice were given a final booster injection of purified MEP. Spleens from immunized mice were fused with myeloma cell line SP2/0-Ag 14 , an immunoglobulin nonsecreting strain developed for somatic cell hybridization with immune spleen cells. Cultures were screened for growth starting 7 days after fusion. Wells showing growth were screened for antibodies specific to MEP using a previously described ELISA (11). Cells in wells which were identified as secreting MEP-specific antibody were then cloned using a limiting dilution cloning technique. Clones that grew up were screened for antibody production and wells that were positive in the ELISA were expanded to obtain culture supernatants containing monoclonal antibodies specific to MEP. Two such clones $(11 / 5$ and $5 / 5)$ were used for the studies described herein. The specificity of these monoclonal antibodies for MEP was determined as described previously in an ELISA assay (11) and opsonophagocytic assay (10).

$P$. aeruginosa outer membrane proteins. Outer membranes were isolated by the one step procedure as described (12). The outer membrane proteins were separated by SDS-PAGE using a $14 \%$ acrylamide running gel containing $0.07 \mathrm{M} \mathrm{NaCl}$ (12).

Western electrophoretic blots. Outer membrane proteins were transferred from SDS gels to nitrocellulose paper. Immunoblotting was performed as described (8) using monoclonal antibodies specific for $P$. aeruginosa outer membrane proteins $F$ (MA5-8) and $\mathrm{H} 2$ (MA1-6).

$P$. aeruginosa LPS phenotypes. The LPS phenotype of the $P$. aeruginosa strains was examined by SDS-PAGE of whole cell lysates, followed by staining with silver periodate, according to the method of Hitchcock and Brown (13).

$P$. aeruginosa serotypes. The $P$. aeruginosa strains were serotyped by slide agglutination using commercially prepared antisera (Difco Laboratories, Detroit, MI).

Serum sensitivity testing. The P. aeruginosa strains were tested for their sensitivity to serum using the two methods described previously (14).

Immunofluorescence of in vitro grown bacteria. Indirect immunofluorescence was performed as described previously (8). Bacteria were grown overnight on Mueller Hinton agar, harvested with sterile swabs, spread on glass slides, and heat fixed. Working dilutions of rabbit polyclonal antibodies (1:1000) and mouse monoclonal antibodies (1:100) were prepared in PBS/ FCS. Bacterial smears were incubated with the antibodies or PBS control at room temperature for $30 \mathrm{~min}$, washed three times with PBS/FCS, and then incubated with a 1:20 dilution of fluoresceinated antirabbit or antimouse $\mathrm{F}\left(\mathrm{ab}^{\prime}\right)$ 2-specific IgG (Cappel Laboratories, West Chester, PA) for $30 \mathrm{~min}$ at room temperature. The slides were washed four times with PBS/FCS, air dried, and examined at 1000 -fold magnification with a Zeiss epifluorescence microscope. The observer was blinded as to the identity of each slide and they were scored as 0 to $4+$ as determined by the intensity of the fluorescence.

Immunofluorescence studies of lung tissue. Biopsies of the lung were obtained at autopsy, 3.5 and $8 \mathrm{~h}$ postmortem. The lung tissue was immediately frozen in isopentane and chilled in liquid nitrogen. Cryostat sections were prepared for direct immunofluorescence using fluoresceinated antihuman $\mathrm{IgG}$, (Fab specific and $\mathrm{Fc}$ specific) and fluoresceinated antihuman $\operatorname{IgA}, \operatorname{IgM}, \mathrm{C} 3$, and C4 (Cappel Laboratories). Control lung tissue was obtained from a 13-yr-old girl with juvenile rheumatoid arthritis and interstitial lung disease. Histological evaluation revealed acute and chronic inflammation of unknown etiology. Sections were examined with a Nikon episcopic fluorescence microscope with blue filter and the intensity of fluorescence was recorded and graded 0 through $4+$.

For indirect immunofluorescence, cryostat sections from the lung biopsies were incubated with rabbit polyclonal or mouse monoclonal antibodies. Goat antirabbit $\mathrm{IgG}$ and goat antimouse $\mathrm{IgG}$ (Cappel Laboratories) were used as the fluoresceinated second antibodies. Specimens were examined and results recorded in the same manner used for the direct immunofluorescence material.

\section{RESULTS}

Outer membrane analysis. The outer membrane protein profiles of the four $P$. aeruginosa strains, subjected to three passages in vitro after isolation from the lungs of the two patients, were nearly identical as assessed by SDS-PAGE analysis (Fig. 1, lanes $A-D$ ), but different from that of the single $P$. maltophilia strain 
from patient 1 (lane E). Immunoblotting analysis after Western transfer of the SDS-P $\wedge$ GI:-separated proteins demonstrated that all four $P$. aeruginosa strains had proteins that reacted with monoclonal antibodies directed against proteins $\mathrm{F}$ and $\mathrm{H}_{2}$ (Fig. 1). Similar protein antigens were not demonstrable on the $P$. maltophilia isolate.

The $P$. acruginosa isolates were assessed with regard to their LPS phenotype. Strains ( $127 / \mathrm{C}$ and $\left(1272 C^{\circ}\right.$ were both nontypable (using the Difeo serotyping scheme). ( $1280 \mathrm{VM}$ and C1295M were both polyagglutinable. The four strains were found to be serum sensitive by the two methods utilized. The two nontypable strains had a lower ratio of smooth to rough I.PS than our standard (14) laboratory strain of P' acruginoses. H 103. when run on SISS-P $\wedge$ GE and stained with silver periodate. The polyagglutinable isolates had approximately the same ratio of smooth to rough I.PS when compared with strain H103.

Immunofluorescence of in vitro grown bateria. All four $P$. aeruginosa isolates reacted with the antibodies directed against whole outer membranes, protein $F$, protein $\mathrm{H} 2$, and the MEP (Table 1). Both mucoid and nonmucoid isolates reacted equally well with the anti-MEP immunoglobulins. The $P$. maltophilia isolate did not react with any of the antibodies except for an equivocal reaction with the anti-MFP Mab 5/5.

Indirect immunofluorescence of hung tissue. Lung tissue sections from both patients with (Cl: reacted with all anti-Pseudomonas immunoglobulins and monoclonal antibodies tested (Table 2). The fluorescence pattern was either in the form of short rods or filaments that were approximately the size of bacteria. The non-CF control failed to fluoresce with any of the antisera tested. The MEP antisera (both monclonal and polyclonal) reacted with bacteria in both lung specimens despite the fact that mueoid $P$. actuginosa had not been recovered from the respiratory tract of patient 1.

Direct immunofluorescence of lung tissue. Lung tissue from both patients with $\mathrm{CI}$ : was incubated with fluoresceinated antihuman immunoglobulins and antihuman $\mathrm{C} 3$ and $\mathrm{C} 4$ (Table 3 ).
Fluoreseence was, as above, in the form of short rods but also frequently as long filaments. a pattern similar to that seen for the anti-Pseudomonas antibodies reported in Table 2. These data indicate. but do not prove. that these human components were associated with the surface of bacteria in the Cl: lung. long tissue from both ( $F$ patients fluoresced with antisera to $\operatorname{IgC}$ [both $F\left(a b^{\prime}\right) 2$ and $F e$ specific]. Ig $A$. and $C 3$. There was minimal fluorescence with antiserum to $\operatorname{lgM}$ and none with fluoresceinated anti-C4. The non-CF control lung tissue failed to fluoresce with any of the antiscra.

\section{DISCLISSION}

The host-parasite relationship characteristic of pulmonary infections in patients with $\mathrm{CF}$ is unique $(1,2,15)$. Mucoid strains of $P$. acruginesa. which are frequently extremely susceptible to the bactericidal effect of human serum $(14,16,17)$. establish a chronic bronchitic infection. Once colonization is established. these bacteria are virtually impossible to cradicate (1). The chronic infectious process evolves in the presence of an exuberant humoral immune response $(2.18 .19)$ and an intact phagocytic host defense system (2). All attempts at medical intervention to date have failed to prevent or eradicate these indolent infections.

The control of MFP production by $\mathrm{CF}^{2} P$. acrugimesa isolates is understood poorly. It is not known why these strains are virtually unique to ( $F$ patients and what the trigger is for production of MEP in the CF lung. We have shown previously. and confirm herein. that MEP is present on nonmucoid as well as mucoid colonial variants $(20)$ : it is probably simply claborated in greater quantity by the latter. Both monoclonal and polyclonal antibodies against MEP reacted in vitro with nonmucoid as well as mucoid clinical isolates. Furthermore. these antibodies produced immunofluoresence in lung sections from patient 1 who was colonized only with nonmucoid strains.

Immunization with Pseudomonas vaccines is one therapeutic strategy which has been proposed. This approach will probably

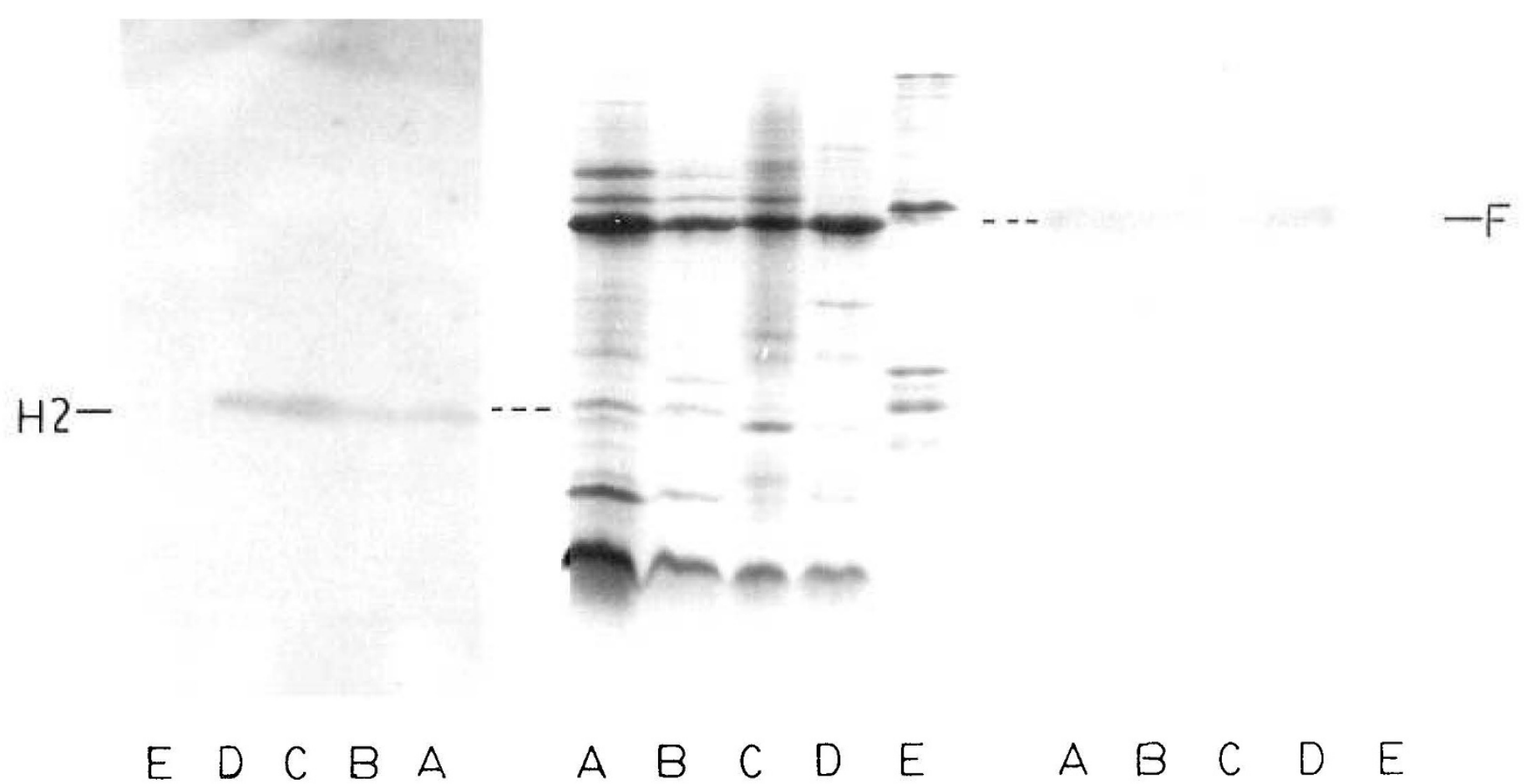

Fig. 1. SDS-PACE: (middl'), and Western immunoblots following electrophoretic transfer to nitrocellulose (left and right), of $l^{\prime}$. aterminima

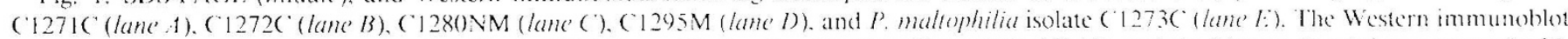
on the left was treated with monoclonal antibody $\mathrm{MAl}-6$, specific for $P$. aerteghosa lipoprotein $\mathrm{H} 2$ (6), and the blot on the rightl was treated with monoclonal antibody MA5-8. specilic for $P$. aerweingese outer membrane protein $F$ (7). Small differences in loading aceounted for the differences in reactivity on the Western immunoblots. 
Table 1. Indirect immunofluorescence of Pseudomonas isolates from patients with $C F$

\begin{tabular}{|c|c|c|c|c|c|c|}
\hline \multirow[b]{3}{*}{ First antibody } & \multirow[b]{3}{*}{$\begin{array}{l}\text { Fluoresceinated } \\
\text { second antibody }\end{array}$} & \multicolumn{3}{|c|}{ Patient 1} & \multicolumn{2}{|c|}{ Patient 2} \\
\hline & & \multicolumn{5}{|c|}{ Bacterial strain } \\
\hline & & $\begin{array}{l}\text { P. aeruginosa } \\
\text { C1271C }\end{array}$ & $\begin{array}{l}\text { P. aeruginosa } \\
\text { C1272C }\end{array}$ & $\begin{array}{l}\text { P. maltophilia } \\
\text { C1273C }\end{array}$ & $\begin{array}{l}\text { P. aeruginosa } \\
\text { C1280NM }\end{array}$ & $\begin{array}{l}\text { P. aeruginosa } \\
\text { C1295M }\end{array}$ \\
\hline $\begin{array}{l}\text { Rabbit antiouter mem- } \\
\text { brane }\end{array}$ & Goat antirabbit IgG & $3+$ & $3+$ & 0 & $3+$ & $2+$ \\
\hline Rabbit anti-MEP & Goat antirabbit IgG & $2+$ & $2+$ & 0 & $2+$ & $2+$ \\
\hline $\begin{array}{l}\text { Affinity-purified rabbit } \\
\text { anti-MEP }\end{array}$ & Goat antirabbit IgG & $2+$ & $2+$ & 0 & $1+$ & $2+$ \\
\hline PBS & Goat antirabbit IgG & 0 & 0 & 0 & 0 & 0 \\
\hline Mouse antiprotein $F$ & $\begin{array}{l}\text { Goat antimouse } \\
\mathrm{IgG}\end{array}$ & $4+$ & $4+$ & 0 & $3+$ & $2+$ \\
\hline Mouse antiprotein $\mathrm{H} 2$ & $\begin{array}{l}\text { Goat antimouse } \\
\mathrm{IgG}\end{array}$ & $2+$ & $3+$ & 0 & $3+$ & $2+$ \\
\hline Mouse anti-MEP (11/5) & $\begin{array}{l}\text { Goat antimouse } \\
\text { IgG }\end{array}$ & $2+$ & $2+$ & 0 & $2+$ & $3+$ \\
\hline Mouse anti-MEP (5/5) & $\begin{array}{l}\text { Goat antimouse } \\
\text { IgG }\end{array}$ & $2+$ & $1+$ & $1+/ 0$ & $2+$ & $2+$ \\
\hline PBS & $\begin{array}{l}\text { Goat antimouse } \\
\text { IgG }\end{array}$ & 0 & 0 & 0 & 0 & 0 \\
\hline
\end{tabular}

Table 2. Indirect immunofluorescence of lung tissue from two patients with $C F$ and from one patient without $C F$

\begin{tabular}{|c|c|c|c|c|}
\hline \multirow[b]{2}{*}{ First antibody } & \multirow{2}{*}{$\begin{array}{l}\text { Fluoresceinated } \\
\text { second antibody }\end{array}$} & \multicolumn{3}{|c|}{ Source of lung tissue } \\
\hline & & CF patient 1 & CF patient 2 & Non-CF control \\
\hline Rabbit antiouter membrane & Goat antirabbit IgG & $3+$ & $3+$ & 0 \\
\hline Rabbit anti-MEP & Goat antirabbit IgG & $2+$ & $3+$ & 0 \\
\hline $\begin{array}{l}\text { Rabbit affinity-purified anti- } \\
\text { MEP }\end{array}$ & Goat antirabbit IgG & $4+$ & $1+$ & 0 \\
\hline Mouse antiprotein $\mathrm{H} 2$ & $\begin{array}{l}\text { Goat antimouse } \\
\text { IgG }\end{array}$ & $2+$ & $3+$ & 0 \\
\hline Mouse antiprotein F & $\begin{array}{l}\text { Goat antimouse } \\
\text { IgG }\end{array}$ & $1+/ 2+$ & $3+$ & 0 \\
\hline Mouse anti-MEP (11/5) & $\begin{array}{l}\text { Goat antimouse } \\
\text { IgG }\end{array}$ & $0 / 1+$ & $1+$ & 0 \\
\hline Mouse anti-MEP (5/5) & $\begin{array}{l}\text { Goat antimouse } \\
\text { IgG }\end{array}$ & $2+/ 3+$ & $2+/ 3+$ & 0 \\
\hline
\end{tabular}

Table 3. Direct immunofluorescence of lung tissue from two patients with $C F$ and from one patient without $C F$

\begin{tabular}{|c|c|c|c|}
\hline \multirow[b]{2}{*}{ Antibody } & \multicolumn{3}{|c|}{ Source of lung tissue } \\
\hline & CF patient 1 & CF patient 2 & Non-CF control \\
\hline $\begin{array}{l}\text { Fluoresceinated antihuman } \operatorname{IgG}, \mathrm{F}\left(\mathrm{ab}^{\prime}\right)^{2} \text { spe- } \\
\text { cific }\end{array}$ & $3+$ & $3+$ & 0 \\
\hline Fluoresceinated antihuman $\operatorname{Ig} G$, Fc specific & $3+$ & $3+$ & 0 \\
\hline Fluoresceinated antihuman IgA & $3+$ & $3+$ & 0 \\
\hline Fluoresceinated antihuman IgM & $1+$ & $1+$ & 0 \\
\hline Fluoresceinated antihuman C3 & $4+$ & $2+$ & 0 \\
\hline Fluoresceinated antihuman C4 & 0 & 0 & 0 \\
\hline
\end{tabular}

be of little value after pulmonary infections are already established, by which time patients have mounted a vigorous antibody response to most $P$. aeruginosa products (21). Indeed Hann and Holscaw (22) previously demonstrated that Pseudomonas strains from the sputum of CF patients were coated with $\mathrm{IgA}, \mathrm{IgG}, \mathrm{IgM}$, and $\mathrm{C} 3$. Our results using direct immunofluorescence examination of lung sections agreed in part with these data by showing that the bacteria in lung sections from both $\mathrm{CF}$ patients were associated with IgG, IgA, and C3 (Table 3). However, despite the presence of such antibodies in established infections, it can be argued that if opsonizing and/or bactericidal antibody could be elicited prior to pulmonary infection, the devastating pulmonary complications of $\mathrm{CF}$ might be prevented or at least forestalled. For immunization to be successful, elicited antibody must recognize surface-exposed bacterial epitopes. The purpose of the studies reported herein was to demonstrate whether or not bacteria present in the CF lung have surface-exposed antigens that are recognized by antibodies raised in vitro against purified $P$. aeruginosa products.

We have demonstrated in these studies, that in the cases studied, $P$. aeruginosa strains in the CF lung have at least some antigenic similarities to those grown in vitro. Monoclonal and polyclonal antibodies raised against purified $P$. aeruginosa MEP and outer membrane proteins $\mathrm{F}$ and $\mathrm{H} 2$ bound to the surfaces of bacteria present in lung tissue from patients with CF. These data are consistent with observations that antibodies to these bacterial products are present in the sera of patients colonized with $P$. aeruginosa $(9,23,24)$. Thus, there is some potential for 
using immunotherapy with these antigens to prevent pulmonary colonization with $P$. aeruginos a of $C F$ patients. For this approach to work, it will probably be necessary to initiate immunotherapy before the first lower respiratory tract infection is established The high levels of anti-Pseudomonas antibodies in the serum of infected $\mathrm{CF}$ patients apparently do little or nothing to enhance clearance of the pathogen. Appropriate vaccine candidates should be 1) broadly reactive with multiple $P$. aeruginosa isolates. 2) directed against surface exposed epitopes, and 3) opsonic. MEP and proteins $\mathrm{F}$ and $\mathrm{H} 2$ appear to satisfy all these criteria. In addition, all three antigens are expressed by $P$. aeruginosd isolates grown in situ in the CF lung. Further investigations with these immunogens are in progress.

Acknowledgments. The authors thank Drs. George Davidson and Lawrence Wong for their cooperation in providing clinica material without which this study would have been impossible.

\section{REFERENCES}

1. Wood RI: Boat TF, Doershuk CF: 1976 (ystic fibrosis. Am Rev Respir Dis $113: 833-878$

2. Speert DP 1985 Host defenses in cystic fibrosis: modulation by Psendomema aeruginosa. Surv Synth Path Res 4:14-33

3. Fick RB, Naegel (iP, Squier SU. Wood RE: Gee JBI. Reynolds HY 198 Proteins of the cystic fibrosis respiratory tract. J Clin Invest 74:236-24

4. Brown MRW, Anwar H. lambert PA 1984 Evidence that mucoid Pseudemonas aeruginosa in the cystic fibrosis lung grows under iron-restricted conditions. FEMS Microbiol I ett 21:113-117

5. Wahba $A H$, Darrell $3 H 1965$ The identification of atypical strains of Pseudemonas aeruginosa. J Gen Microbiol 38:329-342

6. Mutharia LM. Nicas TI, Hancock REW 1982 Outer membrane proteins of P'seudomonas aerusinosa serotype strains. J Infect Dis 146:770-779

7. Hancock REW. Wieczorek $\triangle$ A. Mutharia I.M. Poole K 1982 Monoclonal antibodies against Pseudomonas acruginosa outer membranc antigens: isolation and characterization. Infect Immun 37:166-171

8. Mutharia I.M. Hancock RI.W 1983 Surface localization of Psendemonas aeruginose outer membrane protein $\mathrm{F}$ by using monoclonal antibodies. Infect Immun 42:1027-1033
9. Pier (iB Matthews WJ Fardly D) 1983 Immunochemical characterization of the mucoid exopolysaccharide of Psedemonas acruginesa. J Infect Dis $147: 494-503$

10. Ames P. DesJardins D. Pier GB 1985 Opsonophagocstic killing activity of rabbit antibody to Psendomomas acrueinosa exonols saccharide. Infiect Immun 49:281-285

11. Bryan I.E. Kureishi A. Rahin HR 198.3 Detection of antibodies to P. acruginos alginate extracellular polysaccharide in animais and cystic fibrosis patient by enzyme-linked immunosorbent assiy. J Clin Microbiol 18:276-280)

12. Hancock REW. Carev AM 1979 Outer membranes of Psetudemonas acrugi nosa: heat and 2-mercaptocthanol-modifiable proteins. I Bacteriol 140):9()? 910

13. Hitcheock P. Brown TM 1983 Microbiological heterogencity among Salmonella lipopolysaccharide chemotypes in silver stained polyacrvlamide gels. J Bacteriol 154:269-277

14. Hancock RFW Mutharia IM (han L Darveau RP Spect D) Pier (iB 198 P'sendomonas aeruginosa isolates from patients with cestic fibrosis: a class of serum-sensitive, nontypable strains deficient in lipofolysaccharide () side chains. Infect Immun 42:170-177

15. Marks MI 1981 The pathogenesis and treatment of pulmonary infictions in patients with cystic fibrosis. J Pediatr 98:173-179

16. Muschel L.H. Ahl LA. Fischer MW 1969 Sensitivity of Psendomonas atrue nose to normal serum and to polymxin. J Bacteriol 98:453-457

17. Høiby N. Olling S 1977 Pseudomomas aeruginosa infection in cystic fibrosis Acta Pathol Microbiol Scand [C] 85:107-114

18. Schwartz. RH 1966 Serum immunoglobulin tevels in (ystic fibrosis. Am J I) Child 11 1:408-411

19. Hoiby N Axelson $\mathrm{VH} 1973$ Identification and quantitation of precipitins against Pse'udomonas acruginowa in patients with cystic fibrosis by means of crossed immunoclectrophoresis with intermediate gel. Acta Path Microbiol Scand $[B] 81: 298-308$

20. Pier (GB. DesJardins D. Aguilar T, Barnard M. Speert I)P 19\$6 Polssaccharide surface antigens expressed by nonmucoid isolates of P'sodomomos alruginosa from cystic fibrosis patients. J ( lin Microbiol 24:189-196

21. Pennington JF. Reynolds HY. Wood RE: Robinson RA. I evine AS 1975 lise of a Psequdomonas acruginosa vaccine in patients with acute leukemia and cystic fibrosis. Am J Med 58:629-636

22. Hann S, Holsclaw DS 1976 Interactions of Pseudememas aeruginose with immunoglobulins and complement in sputum. Infect lmmun 1.4:114-117

23. Spect DP. Iawton D. Mutharia I.M 1984 Antibody to P'seudomemas acrugi nosa mucoid exopolysaccharide and to sodium alginate in crstic fibrosis serum. Pediatr Res 18:431-4,33

24. Hancock REW. Mouat ECA. Speert DP 1984 Quantitation and identification of antibodies to outer-membrane proteins of Pseudomemus acruginesa in sera of patients with evstic tibrosis. J Infect Dis 149:220-226 